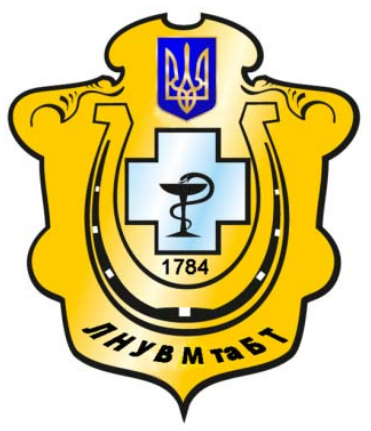

Науковий вісник Львівського національного університету ветеринарної медицини та біотехнологій імені С.3. Гжицького

Scientific Messenger of Lviv National University of Veterinary Medicine and Biotechnologies named after S.Z. Gzhytskyj

doi:10.15421/nvlvet7711

ISSN 2518-7554 print

ISSN 2518-1327 online

$\underline{\text { http://nvlvet.com.ua/ }}$

УДК 619:636.02:636.08.003

\title{
Гематологічні показники та морфологічна характеристика селезінки самок щурів f1 за дії наногерманію цитрату, застосованого у різних дозах
}

\author{
Г.I. Коцюмбас ${ }^{1}$, У.I. Тесарівська², М.I. Гуменецька ${ }^{2}$, М.I. Шумська ${ }^{1}$ \\ pathology@lvet.edu.ua \\ ${ }^{1}$ Львівський націіональний університет ветеринарної медицини та біотехнологій імені С.3. Гэжицького, \\ вул. Пекарська, 50, м. Львів, 79010, Україна; \\ ${ }^{2}$ Державний науково-дослідний контрольний інститут ветеринарних препаратів та кормових добавок, \\ вул. Донецька, 11, Львів, 79019, Україна
}

\begin{abstract}
Представлено результати досліджень впливу «наногерманію» иитрату (НGеL) на гематологічні показники та морфологію селезінки самок щурів F1. Дослідження виконані на 20 самках лабораторних щурів, з яких сформовано 5 груп: I групі (контрольна) випоювали воду, II групі - водний розчин лимонної кислоти в дозі 50 мкг/кг; III групі - з водою 10 мкг Ge, IV групі - з водою 20 мкг Ge, V групі - з водою 200 мкг Ge/кг м. m. НGеЦ самкам випоювали від молочного періоду з матерями F0 і до запліднення, впродовж вагітності та лактаиії. Визначали гематологічні показники, масу та індекси маси $і$ гістологічні зміни селезінки.

Встановлено, що лейкограма крові щурів II, III і IV дослідних груп була зміщена в ліву сторону внаслідок збільшення числа нейтрофілів та еозинофілів. У тварин У групи відзначали тенденцію до зниження лімфочитів, еозинофілів та вірогідне зниження моноцитів і збільшення нейтрофілів. Коефіцієнти маси селезінки тварин IV та V групи тендениійно зростали. Тривале випоювання салкам щурів водного розчину НЦGе у дозі 10 мкг/кг сприяло зростанню кількості клітин білої пульпи, утворенню лімфатичних вузликів з реактивними центтрами, що вказувало на активну лімфопоетичну функиію органа, а 6 дозі 200 мкг/кг спричинило мікроструктурне порушення селезінки і виразилось гіперемією, набряком, повнокрів'ям органу, зменшенням вмісту мікро- $і$ макрофагів та атрофією лімфоїдних вузликів, щъо вказувало на порушення функції лімфоцито-
\end{abstract} поезу.

Ключові слова: щури, наногерманію цитрат, гематологічні показники, селезінка, гістологічні зміни.

\section{Гематологические показатели и морфологическая характеристика селезенки самок крыс f1 при применении наногермания цитрата в разных дозах}

\author{
Г.И. Коцюмбас ${ }^{1}$, У.И. Тесаривская ${ }^{2}$ М.И. Гуменецкая ${ }^{2}$, М.И. Шумская ${ }^{1}$ \\ pathology@lvet.edu.ua
}

\footnotetext{
${ }^{I}$ Львовский нацииональный университет ветеринарной медицины и биотехнологий имени С.3. Гжицкого, ул. Пекарская, 50, г. Львов, 79010, Украина;

${ }^{2}$ Государственный научно-исследовательский контрольный институт ветеринарных препаратов и кормовых добавок, ул. Донеикая, 11, г. Львов, 79019, Украина
}

\footnotetext{
Представлено результаты исследования влияния «наногермания» ичитрата (НGеЦ) на гематологические показатели и морфологию селезенки самок крыс F1. Исследования проводили на 20 самках лабораторных крыс. Сформировано 5 групп: I

\section{Citation:}

Kotsjumbas, G., Tesarivska, U., Humenetska, M., Shumska, M. (2017). Hematological parameters and morphological characteristics of the spleen in female rats f1 under influense nanohermanium citrate, used in different doses. Scientific Messenger LNUVMBT named after S.Z. Gzhytskyj, 19(77), 4550 .
} 
группе (контрольной) випаивали воду, II группе - водный раствор лимонной кислоты в дозе 50 мкг/кг; III группе - с водой 10 мкг Ge, IV группе - с водой 20 мкг Ge, V группе - с водой 200 мкг Gе/кг м. т. НGеЦ крысам выпаивали от молочного периода с матерями FO до осеменения и на протяжении беременности. Определяли гематологические показатели, массу, индекс масы и гистологические изменения селезенки.

Установлено, что лейкограмма крови крыс II, III і IV групп была смещена в левую сторону вследствие увеличения количества нейтрофилов и эозинофилов. У животных V группы отмечали тенденцию к снижению лимфоцитов, эозинофиилов и достоверное снижение моноцитов и увеличение нейтрофилов. Коэфициенты массы селезенки увеличивались у жсивотньх IV ma V группы Длительное выпаивание самкам крыс водного раствора НЦGе в дозе 10 мкг/кг способствовало увеличению количества клеток белой пульпь, образованию лимфатических узликов с реактивными центрами, что указывало на активную лимфопоетическую функцию органа, а в дозе 200 мкг/кг способствовало микроструктурним нарушениям селезенки и виразилось гиперемиею, оттеком, полнокровием органа, снижением количества микро-и макрофагов, а также атрофией лимфотических узликов, что указывало на нарушения функиии лимфочьытопоеза.

Ключові слова: крысы, наногермания иыьтрат, гематологические показатели, селезёнка, гистологические изменения.

\title{
Hematological parameters and morphological characteristics of the spleen in female rats f1 under influense nanohermanium citrate, used in different doses
}

\author{
G. Kotsjumbas ${ }^{1}$, U. Tesarivska ${ }^{2}$, M. Humenetska ${ }^{2}$, M. Shumska ${ }^{1}$ \\ pathology@lvet.edu.ua \\ ${ }^{1}$ Lviv national university of veterinary medicine and biotechnologies named after S. Gzhytskyj, \\ Pekarska Str., 50, Lviv, 79010, Ukraine; \\ ${ }^{2}$ State Scientific-Research Control Institute of Veterinary Medicinal Products and Feed Additives, \\ Donetska Str., 11, Lviv 79019, Ukraine
}

The article presents results of drinking by female rats the water contained different doses of nanogermanium citrate (NGeC). Studies performed on laboratory rats females F1, divided into 5 groups: I - control, II group - aqueous solution of citric acid at a

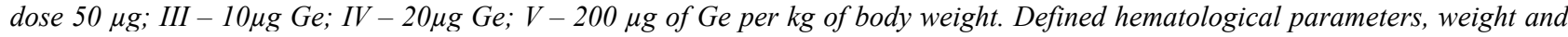
index mass and histological changes in spleen.

From blood leucogram was established that rats from group II, III and IV had incresed the amount of neutrophils and eosinophils. Animals Group V biased marked decrease of lymphocytes and eosinophils, certain decrease of monocytes and increase of neutrophils. Index mass of spleen biased increased in animals $I V$ and $V$ groups. Prolonged drink to female rats aqueous solution of $\mathrm{NGeC}$ at a dose of $10 \mu \mathrm{g} / \mathrm{kg}$ promoted the growth of number cells of white pulp and the formation lymph nodes with reactive centers. This indicates an active limphopoetic function of spleen. But a dose of $200 \mu \mathrm{g} / \mathrm{kg}$ - led to structural disorder that manifested hyperemia, edema, easing trabecular content and reduced lymphocytes, macrophages and microphages of white pulp. This points to the dysfunction lymphocytopoiesis.

Key words: rats, nanohermanium citrate, hematologic parameters, spleen, histological changes.

Вступ

Найбільшим досягненням нанотехнологій на цей час є створення вже цілої індустрії з виробництва різноманітних наноматеріалів - об'єктів, в яких хоча б один 3 розмірів був менше ніж 100 нанометрів $\left(1 \mathrm{HM}=10^{-9} \mathrm{M}\right)$.

Доклінічні та клінічні випробування різних органічних і комплексних германійвмісних сполук, у тому числі отриманих методом нанотехнологій, показали, що вони позитивно впливають на організм (Sakhandra, 2014; Khrabko and Dolaichuk, 2015; Lukianchuk et al., 2016; Khrabko et al., 2016). Серед біологічних властивостей препарату можна відзначити його здатність забезпечувати перенесення кисню в тканини, проявляти антиоксидантну дію (Nemjatyh, 2003; Khrabko, 2010). Однак гістоструктура органів імунної системи, а зокрема селезінки, за впливу наноаквацитрату германію досі не були досліджені. Тому метою досліджень було вивчити особливості гістоструктури селезінки за впливу цитрату германію, застосованого у різних дозах, отриманого на основі використання нанотехнології.
Матеріал і методи досліджень

Дослідження проводили на лабораторних щурах, які утримувались у віварії ДНДКІ ветпрепаратів і кормових добавок у стандартних умовах 3 дотриманням біоетичних вимог. Тваринам випоювали 3 добовою нормою води різні концентрації наногерманію цитрату (НGеЦ) в період фізіологічного і статевого дозрівання, запліднення і вагітності та вигодовування потомства у поколінні F0 та F1. Формування груп самок проводили у віці 3-3,5 місяця з масою тіла $182-$ 218 г. Тваринам дослідних груп (по 4 самки в кожній групі) разом 3 потомством випоювали НGеЦ в таких дозах: II групі - 2\% р-н цитрату; III групі - НЦGe в дозі 10 мкг/кг м.т., IV - групі - 20 мкг/кг м.т., V групі - в дозі 200 мкг/кг маси тіла. Контрольні тварини (I група) мали постійний доступ до питної води. Упродовж дослідження визначали масу тіла самок F1. На 21 добу вагітності у самок відбирали кров, виводили 3 експерименту під впливом легкого ефірного наркозу. Проводили розтин тварин, відбирали імунні органи, визначали масу і вагові коефіцієнти маси селезінки. Зразки селезінки фіксували в 10\% нейтральному формаліні, зневоднювали у спиртах, заливали в парафін. 
Виготовляли гістозрізи і фарбували гематоксиліном та еозином.

У методологічну основу роботи з вивчення дії цитрату германію покладено методичні рекомендації, викладені в довіднику «Доклінічні дослідження ветеринарних лікарських засобів» (Kotsiumbas, 2006). Отриманий цифровий матеріал обробляли загальноприйнятими методами статистичного аналізу на комп'ютері за допомогою програм MS Excel i StatGraphics Plus 2.1.

\section{Результати та їх обговорення}

Аналізуючи результати гематологічних показників дослідних груп, варто зазначити, що у щурів II, III i V груп тенденційно, а в IV групі вірогідно знижувалась кількість еритроцитів. У IV групі цей показник порівняно з контрольною групою знизився на 39\%. При цьому рівень гематокриту у щурів дослідних груп тенденційно зростав на 6-28\%. Вміст гемоглобіну у тварин II групи порівняно 3 контрольною групою, тенденційно знижувався і становив 105,47 г/л, що може вказувати на анемічний стан, у щурів III групи перебував на рівні контролю, а у IV i V групах його рівень був більшим на 3,4-6,7\% відповідно. Разом 3 тим у щурів II, III i V дослідних груп спостерігалось тенденційне, а у IV групі достовірне збільшення кількості лейкоцитів (на 21\%). Лейкограма крові щурів II, III i IV дослідних груп була зміщена в ліву сторону внаслідок збільшення числа нейтрофілів та еозинофілів. У тварин V групи відзначали вірогідне збільшення нейтрофілів, зниження моноцитів і тенденційне зниження лімфоцитів та еозинофілів $(\mathrm{P}<0,05)$ (табл. 1).

Макроскопічно селезінка у тварин контрольної і дослідних груп мала видовжену стрічкоподібну форму, вишневого кольору, пружної консистенції, капсула гладенька. У тварин IV та V групи візуально орган збільшений, краї притуплені, зіскріб пульпи на розрізі наявний. При аналізі вагових показників органа, виявлено тенденційне збільшення маси селезінки у III, IV та V груп, яка становила 1,35 г; 1,42 г (P < 0,05) та 1,78 г (Р < 0,01) відповідно, а в контрольній групі 1,04 г. При визначенні коефіцієнтів маси органа виявили, що ці показники тенденційно зростали у тварин IV та V групи (табл. 2).

При гістологічному дослідженні селезінки щурів контрольної групи відзначали, що поділ на червону і білу пульпу збережений, трабекулярна будова виражена. Червона пульпа помірно кровонаповнена, інфільтрована мікро- та макрофагами i проглядались мегакаріоцити. Лімфатичні вузлики білої пульпи кулястої форми, компактно заселені лімфоцитами (рис.1). В них чітко виражена периартеріальна, маргінальна і мантійна зони (рис. 2).

У селезінці щурів II групи, яким випоювали водний 2\% р-н цитрату, відзначали, що біла пульпа представлена лімфатичними вузликами переважно овальної форми, в них зменшений вміст лімфоцитів у мантійній зоні (рис. 3).

Разом $з$ тим в органі збільшувалась кількість лімфатичних вузликів зі світлими зонами, в яких переважали лімфобласти, ретикулярні клітини (рис. 3). При цьому слід відзначити, що в червоній пульпі селезінки щурів II групи зростав вміст крові, гемосидерину, мікро- і макрофагів. Часто візуалізувались мегакаріоцити зі світло-базофільними ядрами. Синуси, судини розширені, переповнені кров'ю (рис. 4).

У селезінці щурів ІІІ груп яким випоювали НЦGe в дозі 10 мкг/кг відзначали порівняно з контрольними тваринами збільшення об'єму білої пульпи. Лімфатичні вузлики переважно кулясто-овальної форми, компактно заселені лімфоцитами. В них добре проглядається периартеріальна та маргінальна зони 3 різним типом клітин: Т- і В-лімфоцити та макрофаги. У м'якушевих тяжах червоної пульпи зростала кількість нейтрофілів, макрофагів, лімфоцитів, плазматичних клітин (рис. 5).

Серед клітин проглядались мегакаріоцити із темно забарвленими ядрами. Виявляли також лімфатичні вузлики з реактивними центрами (рис. 6). Структурні зміни вказували на активну лімфопоетичну функцію органа.

Табличя 1

Гематологічні показники самок щурів $\mathrm{F}_{1}$ за дії різних доз цитрату германію.

\begin{tabular}{|l|c|c|c|c|c|}
\hline \multirow{2}{*}{\multicolumn{1}{|c|}{ Показник }} & \multicolumn{4}{|c|}{ Група } \\
\cline { 2 - 6 } & контроль & цитрат & \multicolumn{3}{c|}{ дослід, мкг Ge/кг маси тіла } \\
\cline { 2 - 6 } & $\mathrm{I}$ & $\mathrm{II}$ & $\mathrm{III}-10$ & $\mathrm{IV}-20$ & $\mathrm{~V}-200$ \\
\hline Еритроцити, Т/л & $6,0 \pm 0,8$ & $5,04 \pm 0,47$ & $4,7 \pm 0,27$ & $4,15 \pm 0,19^{*}$ & $5,35 \pm 0,63$ \\
\hline Лейкоцити, Г/л & $6,5 \pm 0,47$ & $9,26 \pm 0,9^{*}$ & $9,5 \pm 2,54$ & $11,64 \pm 1,8^{*}$ & $8,2 \pm 0,87$ \\
\hline в т.ч.: лімфоцити, \% & $72,8 \pm 2,33$ & $70,8 \pm 1,36$ & $71,3 \pm 1,76$ & $68,7 \pm 2,46$ & $67,3 \pm 2,40$ \\
\hline нейтрофіли, \% & $23,6 \pm 1,94$ & $24,8 \pm 1,5$ & $25,3 \pm 1,33$ & $27,5 \pm 2,83$ & $31,3 \pm 1,76^{*}$ \\
\hline еозинофіли, \% & $0,80 \pm 0,49$ & $1,6 \pm 0,4$ & $1,37 \pm 0,63$ & $2,22 \pm 0,79$ & $0,67 \pm 0,07$ \\
\hline моноцити, \% & $2,80 \pm 0,49$ & $2,8 \pm 0,49$ & $2,00 \pm 0,02$ & $1,68 \pm 0,32$ & $0,67 \pm 0,07^{*}$ \\
\hline Гематокрит, \% & $37,0 \pm 0,58$ & $39,2 \pm 1,99$ & $46,67 \pm 4,41$ & $39,17 \pm 4,41$ & $47,33 \pm 2,67$ \\
\hline Гемоглобін, г/л & $146,3 \pm 7,2$ & $105,5 \pm 12,6$ & $141,1 \pm 21,4$ & $151,3 \pm 9,87$ & $156,1 \pm 12,54$ \\
\hline
\end{tabular}

Табличя 2

Коефіцієнти маси селезінки самок щурів F1 при дослідженні наноаквацитрату германію

\begin{tabular}{|l|c|c|c|c|c|}
\hline & $\begin{array}{c}\text { I група } \\
\text { (контроль) }\end{array}$ & $\begin{array}{c}\text { II група } \\
\text { (цитрат) }\end{array}$ & $\begin{array}{c}\text { III група } \\
(10 \text { мкг/кг) }\end{array}$ & $\begin{array}{c}\text { IV група } \\
(20 \text { мкг/кг) }\end{array}$ & $\begin{array}{c}\text { V група } \\
(200 \text { мкг/кг) }\end{array}$ \\
\hline Вага & $1,04 \pm 0,08$ & $1,02 \pm 0,15$ & $1,35 \pm 0,16$ & $1,42 \pm 0,1 *$ & $1,78 \pm 0,16^{* *}$ \\
\hline Індекс маси & $4,85 \pm 0,63$ & $4,94 \pm 0,49$ & $4,57 \pm 0,84$ & $5,91 \pm 0,56$ & $6,79 \pm 1,04$ \\
\hline
\end{tabular}




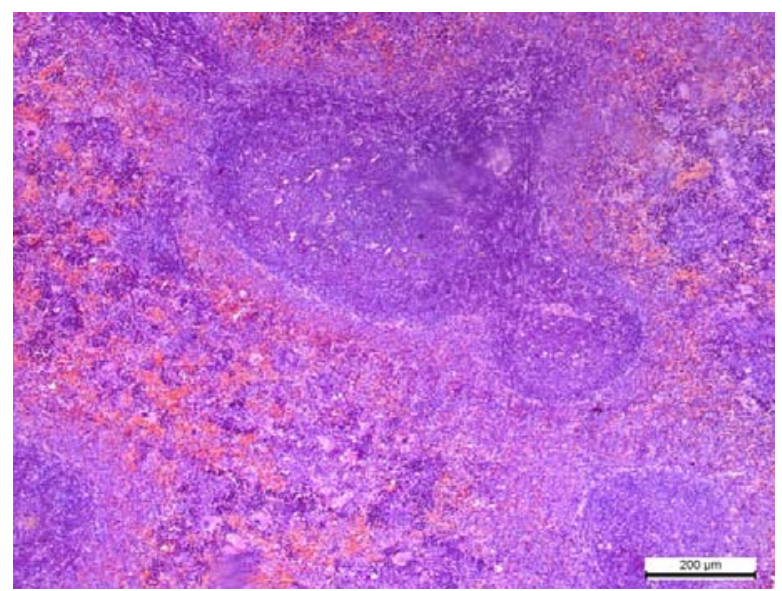

Рис. 1. Селезінка щурів контрольної групи. Лімфатичні вузлики. Гематоксилін та еозин. Ок. 10 , об. 10

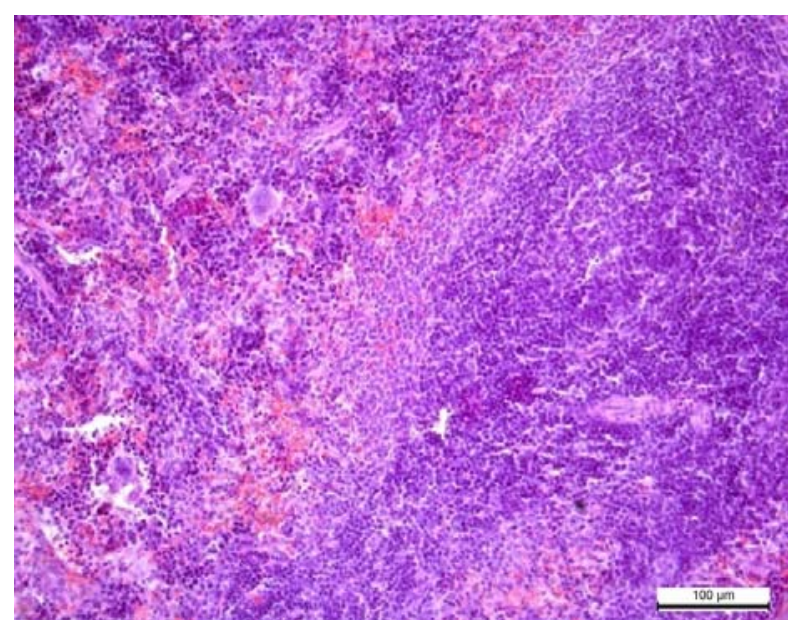

Рис. 3. Селезінка щурів II групи. Лімфатичні вузлики. Гематоксилін та еозин. Ок. 10, об. 20

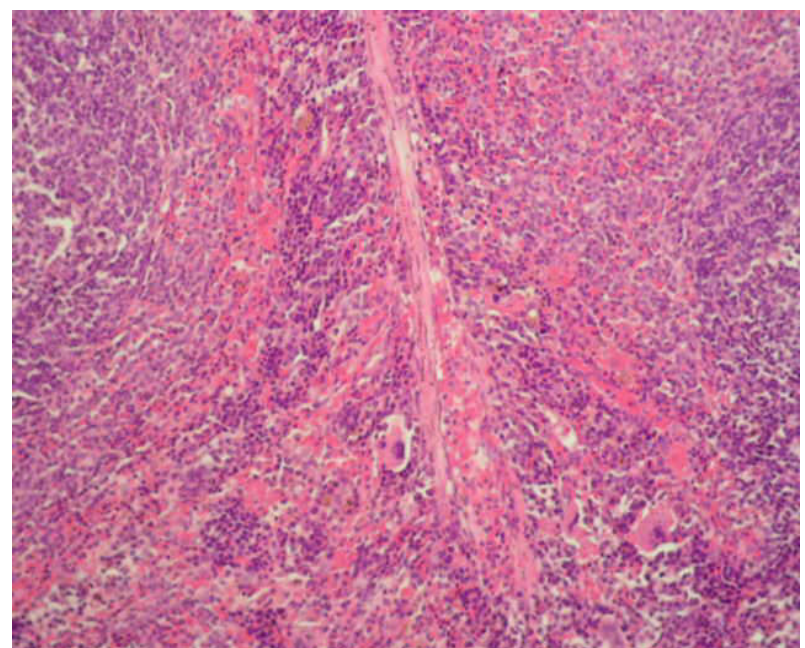

Рис. 5. Селезінка щурів III групи. Лімфатичні вузлики. Гематоксилін та еозин. Ок. 10, об. 20

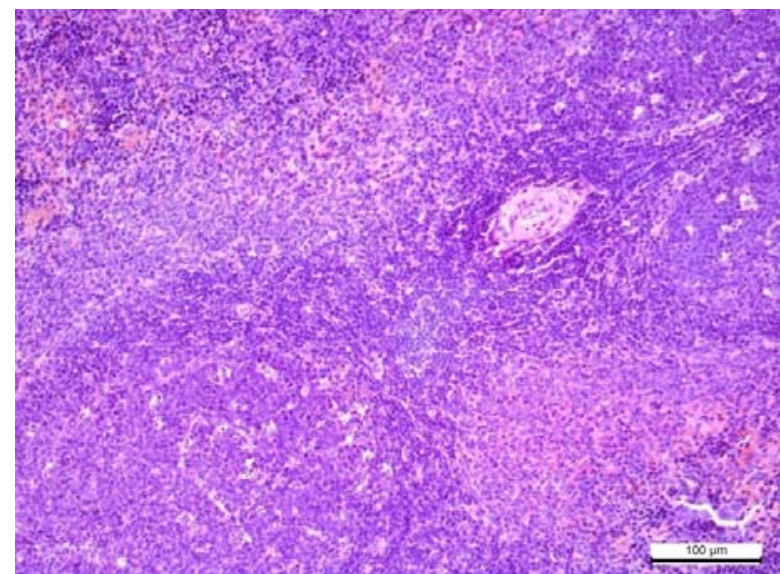

Рис. 2. Селезінка контрольної групи. Лімфатичний вузлик. Чітко виражена периартеріальна, маргінальна і мантійна зони. Гематоксилін та еозин. Ок. 10 , об. 20

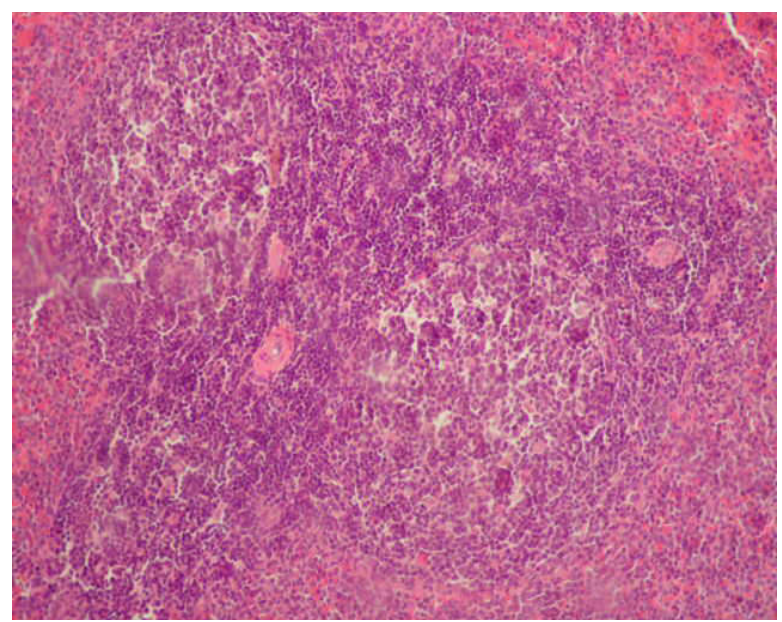

Рис. 4. Селезінка щурів II групи. Лімфатичні вузлики зі світлими центрами. Гематоксилін та еозин. Ок. 10, об. 20

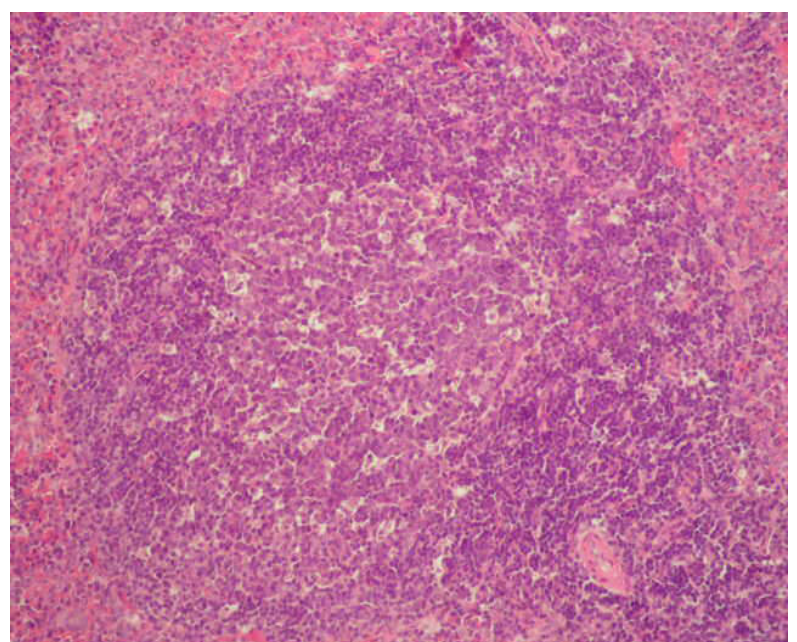

Рис. 6. Селезінка щурів III групи. Лімфатичний вузлик 3 реактивним центром. Гематоксилін та еозин. Ок. 10 , об. 20 
У селезінці самок щурів IV групи, яким випоювали водний розчин НЦGе у дозі 20 мкг/ кг, виражене порушення гемодинаміки. Синуси, судини розширені, переповнені кров'ю. Виражена гіперемія, набряк зумовили деструктивні зміни в організації ретикулярних клітин, помірне розволокнення трабекул і стінок судин. У червоній пульпі зростав вміст крові. Зменшувалась відносна площа лімфатичних вузликів. При

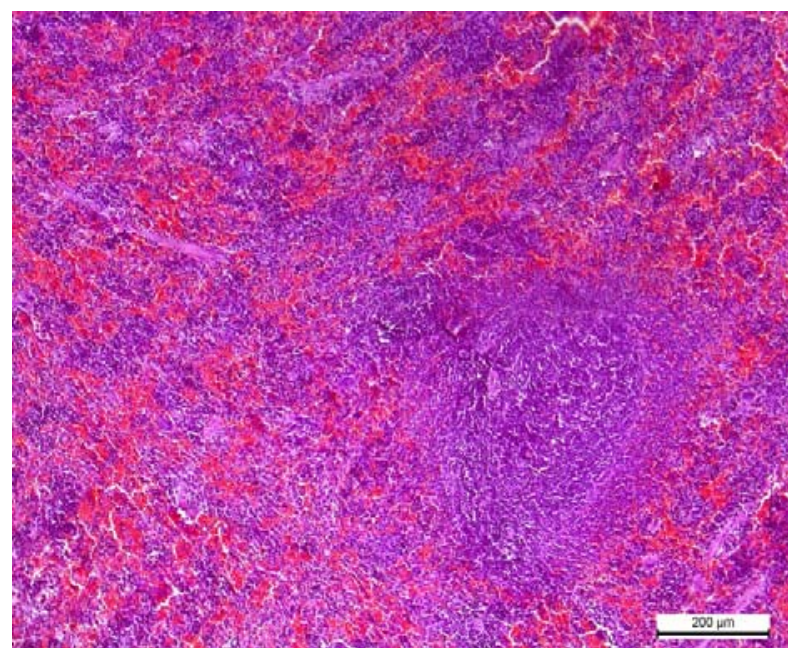

Рис. 7. Селезінка щурів IV групи. Лімфатичний вузлик. Гіперемія. Гематоксилін та еозин. Ок. 10 , об. 10

Гістоструктура селезінки щурів V групи, яким випоювали НЦGe у дозі 200 мкг/кг, характеризувалась різким порушенням гемодинаміки та кровонаповненням червоної пульпи. Відзначався набряк, розволокнення трабекул і стінок судин. Ендотеліальні клітини часто набували міхурцеподібної форми, тобто перебували в стані гідропічної дистрофії. Клітини виступали в просвіт судин. Внутрішня еластична пластинка окремих судин слабо забарвлювалась еозином, контури ставали нечіткими. Деструкція ендотеліоцитів 3 явищами розволокнення стінки судин сприяло підвищенню їхньої проникності 3 розвитком навколосу-

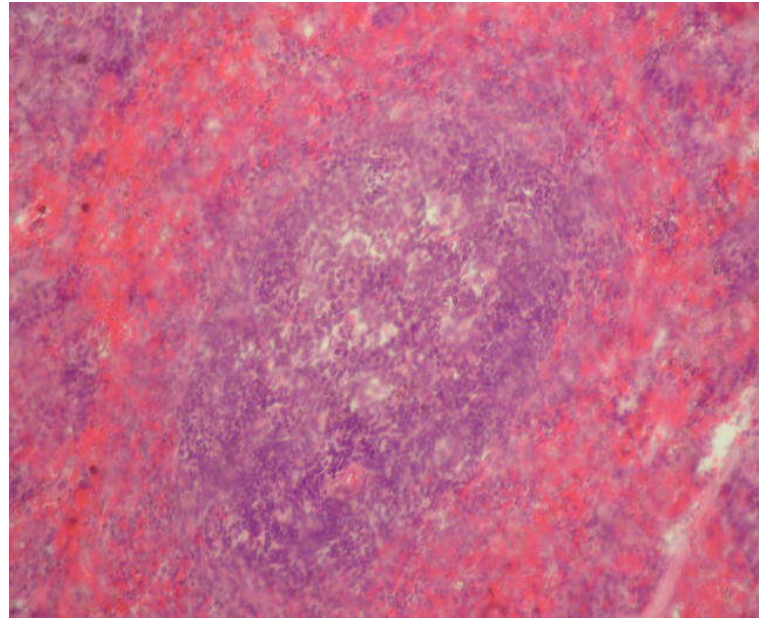

Рис. 9. Селезінка щурів V групи. Лімфатичні вузлики зменшені. Гематоксилін та еозин.

Ок. 10 , об. 20 цьому периартеріальна зона лімфатичних вузликів компактно заселена лімфоцитами, а в маргінальній зоні зменшена кількість середніх лімфоцитів і різко звужена мантійна зона (рис. 7). Зростання вагових коефіцієнтів селезінки щурів IV групи зумовлено збільшенням вмісту крові в червоній пульпі при зменшені клітин білої пульпи.

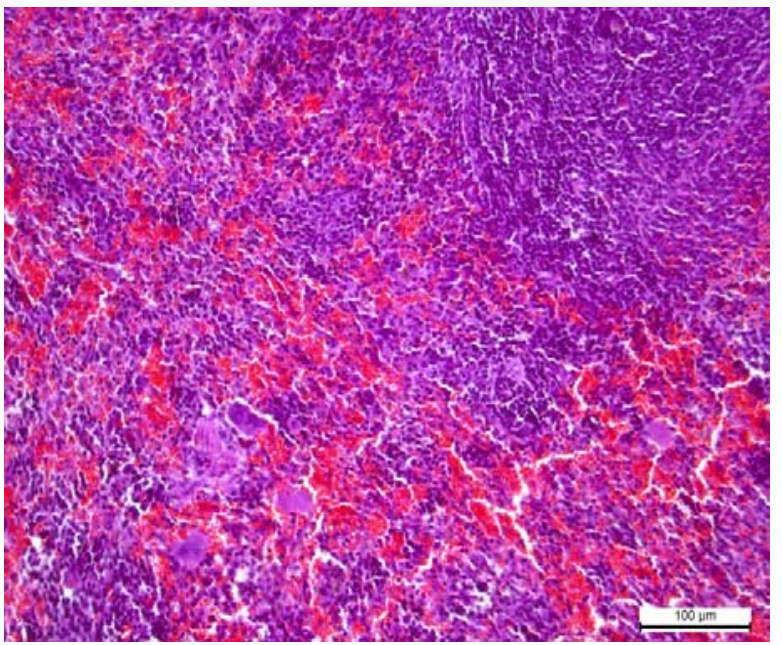

Рис. 8. Селезінка щурів IV групи. Синуси переповнені кров'ю. Зменшення маргінальної і мантійної зон лімфатичного вузлика. Гематоксилін та еозин. Ок. 10, об. 20

динного набряку та плазматичного просочування стінок судин. Отже, порушення гемодинаміки віддзеркалились явищами стромального і периваскулярного набряків тканини. На тлі різкого повнокрівя добре проглядалось різке зменшення - атрофія лімфатичних вузликів. У червоній пульпі проходив більш інтенсивний розпад еритроцитів і нагромадження гемосидерину. У м'якушевих шнурах зменшувався вміст мікро- та макрофагів. Різке повнокрівя пульпи, набряк та розволокнення трабекул зумовило зростання коефіцієнтів маси органа (рис. 10).

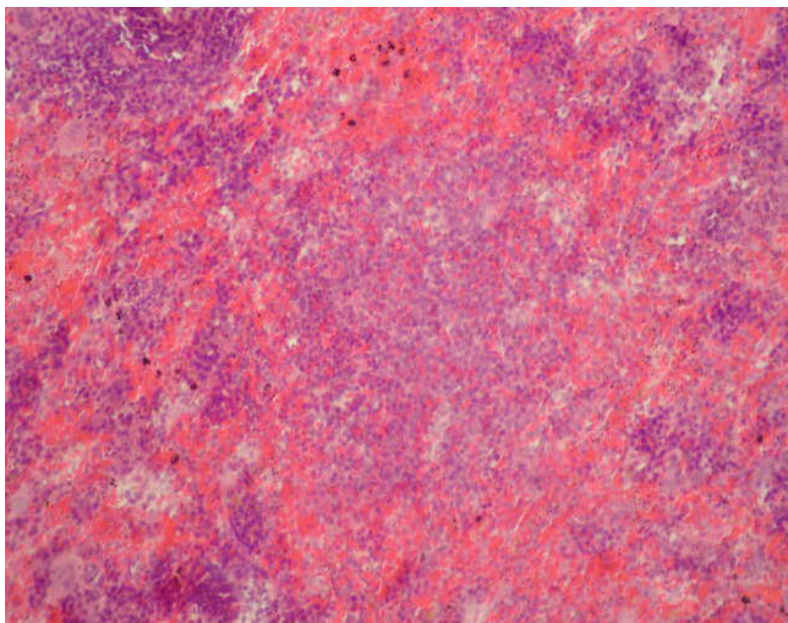

Рис. 10. Селезінка щурів V групи. Різке повнокрів'я червоної пульпи. Зростання вмісту крові, гемосидерину та мегакаріоцитів. Гематоксилін та еозин. Ок. 10 , об. 20 
На тлі різкого повнокрів'я відзначалась атрофія лімфатичних вузликів. Вони не мали чітко окреслених зон, розміри їх маленькі, мантійна зона витончена. Центри розмноження лімфатичних вузликів розпушені, в них відзначається каріорексис клітин різної інтенсивності. Зменшення центрів розмноження та витончення мантійної зони вказувало на різке пригнічення активності Т-лімфоцитів (рис. 9). Виявлене порушення структури селезінки вказували на послаблення клітинного імунітету і функціонування імунної системи, що віддзеркалилось тенденційним зниженням лімфоцитів у крові. Виявлені зміни вказують на пригнічення лімфопоетичної функції органа.

\section{Висновки}

Тривале випоювання самкам щурів водного розчину НЦGe у дозі 10 мкг/кг сприяло зростанню кількості клітин білої пульпи, утворенню лімфатичних вузликів 3 реактивними центрами, що вказувало на активну лімфопоетичну функцію органа, а в дозі 200 мкг/кг спричинило структурне порушення селезінки, що проявилось гіперемією, набряком, повнокрів'ям органа, зменшенням вмісту мікро- і макрофагів та атрофією лімфоїдних вузликів і вказувало на пригнічення функції лімфоцитопоезу. Тенденційне зростання вагових коефіцієнтів селезінки у тварин IV i V груп було зумовлене кровонаповненням червоної пульпи.

\section{Бібліографічні посилання}

Lukianchuk, V.D., Seifullina, I.I., Litvynenko, D.F., Martsynko, O.E. (2016). Farmakolohichni vlastyvosti orhanichnykh i koordynatsiinykh spoluk hermaniiu - suchasni uiavlennia. Farmakolohiia ta likarska toksykolohiia. 1(47), 3-13 (in Ukrainian).

Sakhandra, I.V. (2014). Preparaty hermaniiu ta yikh zastosuvannia $\mathrm{v}$ medytsyni. Ukrainskyi naukovomedychnyi molodizhnyi zhurnal. 4(84), 83-86 (in Ukrainian).

Khrabko, M.I., Dolaichuk, O.P. (2015). Reproduktyvna funktsiia ta masa samok shchuriv i zhyttiezdatnist pryplodu za vypoiuvannia nano - ta khimichno syntezovanoho tsytratu hermaniiu. Biolohiia tvaryn. 17(4) (in Ukrainian).

Khrabko, M., Fedoruk, R., Dolaichuk, O. (2016). Fizioloho-biokhimichni protsesy v orhanizmi samyts F0 i samtsiv F1 shchuriv za umov vypoiuvannia yim «nanohermaniiu» tsytratu i tsytratu hermaniiu khimichno syntezovanoho. Visnyk Lvivskoho universytetu. 73, (in Ukrainian).

Nemjatyh, O.D. (2003). Poisk sredstv profilaktiki gipoksii zamknutogo prostranstva: avtoref. dis. na zdobuttja nauk. stupenja kand. med. nauk ; special'nist' 14.03.05 «farmakologija» Lugans'k (in Russian).

Khrabko, M.I. (2010). Antyoksydantna aktyvnist ta dezintoksykatsiina zdatnist orhanizmu shchuriv za zghodovuvannia tsytrativ khromu, selenu ta hermaniiu. Biolohiia tvaryn. 49-54 (in Ukrainian).

Kotsiumbas, I.Ia. (2006). Doklinichni doslidzhennia veterynarnykh likarskykh zasbiv. Za red. d.v.n., prof. I.Ia. Kotsiumbasa. Lviv: Triada plius (in Ukrainian).

Merkulov, G.A. (1961). Kurs patogistologicheskoj tehniki. Moskva. (in Russian).

Vershigora, A.E. (1980). Osnovi immunologii. Rukovodstvo. 2-e izd. ispr. i dop. Kiev. Vishha shkola. Golovnoe izd-vo. (in Russian).

Serov, V.V. (1983). Itogi nauki i tehniki. Patologicheskaja anatomija. Moskva. 4 (in Russian).

Стаття надійшла до редакиії 20.03.2017 